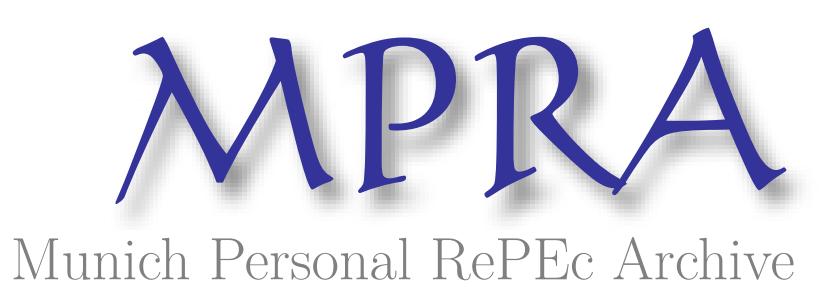

\title{
The need for revised resolution regimes and supervisory arrangements
}

\author{
Ojo, Marianne
}

September 2011

Online at https://mpra.ub.uni-muenchen.de/33674/

MPRA Paper No. 33674, posted 23 Sep 2011 17:09 UTC 


\begin{abstract}
In October 2010, having drawn crucial lessons fom the Financial Crisis which was triggered in 2007, and whose impact was still evident at the time, the Financial Stability Board Recommendations on systemically important financial institutions ,called for an assessment, on the basis of the BCBS Recommendations and the draft FSB Key Attributes of Effective Resolution Regimes (FSB Key Attributes), of national authorities' capacity to resolve SIFIs under existing resolution regimes and of the legislative and other changes to national resolution regimes and policies needed to accomplish effective resolution."

As well as attempting to highlight why much greater initiatives and efforts are required in relation to exit mechanisms for failing banks - that is, greater initiatives and efforts than prudential aspects of regulation which embrace capital adequacy procedures, this paper also draws attention to vital steps that could be taken at international level to make cross-border resolutions more effective.
\end{abstract}

Key Words: lender of last resort, special resolution regime, Financial Crisis, liquidation, bankruptcy, systemic risks, living wills, bailing in, resolution procedures, deposit protection, liquidity 


\title{
The Need for Revised Resolution Regimes and Supervisory Arrangements
}

\author{
Marianne Ojo
}

\section{A. Introduction}

Maintaining the close involvement of national central banks in prudential supervision has been highlighted by the European Central Bank (ECB) as a vital pre requisite, not only in facilitating the Euro system's adequate contribution to monitoring risks to financial stability in the Euro zone, but also in ensuring smooth coordination between central bank functions which are carried out at supra national level and supervisory functions carried out at national level. ${ }^{2}$ It has been observed that since the start of the Crisis, the ECB has complained of a lack of information on banks which have the potential to trigger systemic failures. ${ }^{3}$ Further, the existence of legal impediments to the sharing of information between national regulators in the Euro zone and the ECB has been noted. ${ }^{4}$

An approach whereby a European system of supervisory agencies consisting of national prudential agencies which would be aggregated within a single supervisory system with cross border structures - similar to the European System of Central Banks, has been proposed. ${ }^{5}$ Further, a European prudential supervisory agency would not only be responsible for strategic supervisory decisions, but also the design of policies. ${ }^{6}$ It would also assist in the resolution of disputes between home and country supervisors. ${ }^{7}$

The task of harmonisation in the area of bank regulation and supervision in the Euro zone however, appears to be a daunting one. Given the diverse structures of regulation across Euro member states, it is not so difficult to understand why the ECB has no formal supervisory role. ${ }^{8}$ The recommendations of the Report of the High Level Group on Financial Supervision in the EU, which are aimed at re building the structure of financial regulation and supervision in the EU, consist of three new elements. ${ }^{9}$

Financial crises such as those of Northern Rock, IKB and Hypo Real Estates in Europe, have lead to

1 Contact Email: marianneojo@hotmail.com

2 LB Smaghi, 'Central Bank Independence in the EU: From Theory to Practice' European Law Journal, Vol. 14, No. 4, July 2008, p 454.

3 W Buiter, Central Banks and Financial Crises (Paper presented at the Federal Reserve Bank of Kansas City's symposium on "Maintaining Stability in a Changing Financial System", at Jackson Hole, Wyoming, on August 2123,2008 ) at page 113.

4 ibid

5 See J Lawson and S Barnes and Marte Sollie 'Financial Market Stability in the European Union: Enhancing Regulation and Supervision' Economics Department Working Paper No. 670 page 37 and also D Schoenmaker and S Oosterloo, "Financial Supervision in Europe: A Proposal for a New Architecture", in: L. Jonung, C. Walkner and M. Watson (eds), Building the Financial Foundations of the Euro - Experiences and Challenges, 2008 Routledge,

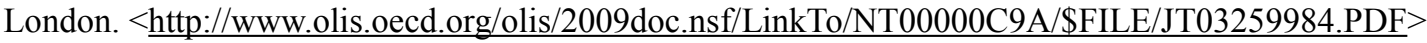

6 ibid

7 ibid

8 See W Buiter, Central Banks and Financial Crises at page 113.

9 See W Nier, 'Financial Stability Frameworks and the Role of Central Banks: Lessons from the Crisis' IMF Working Paper WP/09/70 April 2009 at pages 21 and 22; Also see De Larosière, 2009, "Report of the High-level Group on 
a review of arrangements involving the central banks in the jurisdictions concerned. The occurrence of these crises also highlighted the need for a special resolution regime and a "bridge bank" whose aims are to address the needs of failing banks.

\section{B. Resolution Regimes and the Central Bank's Role in Maintaining Financial Stability}

\section{Resolution Regimes}

„The terms "resolution" and "resolution regime" are understood as referring to any action by a national authority, with or without private sector involvement, intended to maintain financial stability and/or address serious problems in a financial institution that imperil its viability (eg a substantive condition of authorisation) where, absent resolution, the institution is no longer viable and there is no reasonable prospect of it becoming so." ${ }^{\prime 10}$

Three types of resolution regimes as identified, ${ }^{11}$ are as follows:

\section{Special resolution regimes :}

- These enable authorities to take control of banks and other financial group companies before or upon insolvency and that provide a wider range of resolution or stabilisation powers thereafter. Full-blown special resolution regimes are mainly administrative regimes, and they provide directed transfer powers. This includes an ability to effect partial transfers of the assets and liabilities of the financial institution to third party purchasers or bridge institutions, without needing to obtain the consent of shareholders, creditors and counterparties of the failed institution.

Special administration or management $\operatorname{regimes}^{12}$

\section{Mixed regimes $^{13}$}

According to Raghallaigh and Kennedy, ${ }^{14}$ principal features of ,special resolution or conservatorship" should provide that:

- the regime is statutory and ex ante

Financial Supervision in the EU," Brussels, Feb 25, 2009. These elements comprise of a macro prudential authority (ESRC), a micro prudential authority (ESFS) and a consolidation of sectoral committees such as those of the CEBS,CEIOPS and CESR which elevates their status to that of "authorities" which are conferred specific powers aimed at guaranteeing consistent supervision across the EU.

10 Basel Committee on Banking Supervision, Resolution Policies and Frameworks - Progress So Far, July 2011, BIS Publications at page 7.

11 See ibid at page 8 .

12 ,which are hybrid administrative/judicial regimes in which the banking supervisors or resolution authorities appoint special officials (variously referred to as special administrators, provisional administrators, special managers or statutory managers) to implement resolutions. They are designed to facilitate a (going concern) restructuring and/or recapitalisation of the failing institution. Should a restructuring not be possible under these regimes, a forced liquidation or bankruptcy-type process generally applies. ,, see ibid

13 which are ,without the full range of powers exhibited by the first two groups, in some cases because the powers can only be exercised with the consent or on a majority vote of shareholders and/or creditors, and in some cases because the regime strongly relies on court-administered proceedings, in particular in the insolvency liquidation phase. These arrangements nevertheless are generally distinct from corporate insolvency procedures." ibid

14 See F Raghallaigh and M Kennedy, „Banking Crises and Special Resolution Regimes“ February 2011 at page 25. 
- It operates within the sphere of public administrative law

- It recognises the systemic nature of banking (the unique nature of banks)

- It enhances the pre-emptive function of conventional oversight (including ultimately through seizure)

- It requires banks to have their own resolution plans (living wills)

- The regulator's toolkit to deal with failure is expanded (typically through the vehicle of bridge banks)

- The regime provides for the cross border or international aspect of banking; and

- It provides for the absorption of losses by loan capital.

\section{The Central Bank's Role in Maintaining Stability.}

Central bank independence has been the preferred means to facilitating monetary stability since the end of the 1980s and the beginning of the 1990s and factors contributing to this include: Fact that in the EU, the Maastricht Treaty on European Union made legal central bank independence a conditio sine qua non to participating in European Monetary Union. This is in addition to the other four criteria of economic convergence and the additional requirements regarding fiscal responsibility. The second factor emanates from the skills, expertise and superior qualifications of central bankers when compared to those of politicians. ${ }^{15}$ The separation or combination of the roles of the central bank as lender of last resort and supervisor constitutes a controversial topic. It is argued that whilst a supervisory authority like the Fed Reserve has greater likelihood to possess "institution specific information" which is vital for performing the LLR role effectively, it is also susceptible to regulatory capture. ${ }^{16}$ Furthermore, supervisory authorities such as the Bank of England and the European Central Bank are considered to be less vulnerable to the possibility of being captured, but not so well informed about impending liquidity or solvency problems in systemically prone and important financial institutions. ${ }^{17}$

In addition to its monetary policy setting functions, there are many reasons in favour of the central bank also acting as supervisor ${ }^{18}$ and these are as follows: That the central bank must have concern for the efficient working of the payments system and that as a result, it should also supervise and regulate at least the main money-market commercial banks at the heart of the system; that any rescue or liquidity crises will usually require quick injection of cash-which can only be done by the central bank. For this reason, it is argued that the central bank and supervisory body work closely together and that this can best be achieved through internalising the supervisory body within the central bank; and that separation would involve wasteful duplication as there is bound to be a lot of overlap between areas of interest of and information required by and accessible to both the supervisor and the central bank.

Arguments for separation include: Where government financing is required for any large rescue, politicians and the Ministry of Finance are likely to be involved. For this reason, it is important for the central bank to become more independent in the conduct of monetary policy and less politically involved in its supervisory role; that bank failures affect credibility and the central bank requires

15 See RM Lastra, Legal Foundations of International Financial Stability 2006 45-46.

16 See for example Buiter 'Central Banks and Financial Crises' at page 120.

17 ibid

18 C Goodhart and D Schoenmaker ' Institutional Separation Between Supervisory and Monetary Agencies ' (Financial Markets Group Special Papers 1992 )140-141; CAE Goodhart The Emerging Framework of Financial Regulation (1998) 249. 
credibility in conducting its monetary policies; and where concerns for the micro-level health and stability of parts of the banking system might affect the aim of the central bank's conduct of monetary macro-policy - that is, where there is conflict of interest between the combination of monetary and regulatory function.

As a result of its business relationships with credit institutions, its local presence and its general proximity to the market, the Bundesbank has deep insights into the financial sector and possesses knowledgeable, qualified staff who deal with issues relating to the financial market and its stability. ${ }^{19}$ It is therefore not surprising that the German Parliament approved the Bundesbank's involvement in banking supervision in section 7 of the Banking Act. ${ }^{20}$ As well as being involved in the supervisory process, the Bundesbank is also involved in matters relating to supervisory policymaking. As a member of the Financial Markets Regulatory Forum, it is acknowledged as an authority that together with BaFin is responsible for the stability of the financial system. ${ }^{21}$

As a result of the Bank of England Act $1998,{ }^{22}$ the Bank of England has a limited role in the regulation and supervision of banks. A review of the extent of the Bank of England's role in bank regulation has achieved partial realisation with the introduction of the 2009 Banking Act.

\section{The Need for a Special Resolution Regime}

The Northern Rock crisis highlighted problems which were inherent in the tripartite arrangement between the Treasury, the Financial Services Authority and the Bank of England for dealing with financial stability which includes amongst others, the inability of the Bank to act as lender of last resort for a limited time without such a role being made public. The consultation paper issued in July $2008,{ }^{23}$ as a response by the authorities to the Northern Rock Crisis and to strengthen the U.K. framework for financial stability, envisaged a leading role for the Bank of England in the implementation of a special resolution regime for banks. ${ }^{24}$

The establishment of a "special resolution regime" which should enable the seizure of a failing bank and facilitate all or part of its business to be transferred to a "bridge bank" which would manage services for customers, is also a consequence of the Northern Rock crisis.

The Banking Act 2009 received Royal Assent on the 12 February 2009 - legislation having been introduced into Parliament on the 7 October 2008. ${ }^{25}$ As well as formalising the role of the Bank of England in its oversight of systemically vital payment systems, the Banking Act 2009 has also resulted in statutory powers being granted to the Bank of England, in respect of its responsibility for financial stability. ${ }^{26}$ The Act is divided into eight sections which deal with the special resolution regime, bank insolvency, bank administration procedures, inter bank payment systems and the Financial Compensation Scheme.

19 Deutsche Bundesbank, „Bundesbank and German Federal Financial Supervisory Authority (BaFin)“ $<\underline{\text { http://www.bundesbank.de/bankenaufsicht/bankenaufsicht bafin.en.php }>}$

20 ibid

21 ibid

22 Whereby powers related to the supervision and regulation of banks were transferred to the Financial Services Authority.

23 HM Treasury, Bank of England and FSA, 2008, "Financial Stability and Depositor Protection: Further Consultation," July 2008.

24 See W Nier, 'Financial Stability Frameworks and the Role of Central Banks: Lessons from the Crisis' IMF Working Paper WP/09/70 April 2009 at page 21.

25 See HM Treasury, „Banking Act 2009“ $<\underline{\text { http://www.hm-treasury.gov.uk/fin banking_act2009.htm }>}$

26 Regulatory and supervisory responsibilities had been formally passed to the Financial Services Authority (FSA) under the Bank of England Act 1998. 
The special resolution regime, which constitutes the focal point, in respect of measures aimed at dealing with failing banks, is the new statutory and permanent regime which consolidates temporary measures introduced by the Banking (Special Provisions) Act 2008 (BSPA) ${ }^{27}$ which was implemented as a means of exercising control and bringing Northern Rock into temporary public ownership in February 2008. According to Part $1^{28}$, section 1 (1) of the Act, the purpose of the special resolution regime for banks is to address the situation where all or part of the business of a bank has encountered, or is likely to encounter financial difficulties. The special resolution regime consists of three stabilisation options, ${ }^{29}$ the bank insolvency procedures ${ }^{30}$ and the bank administration procedures. ${ }^{31}$

The FSA is the triggering authority. The trigger is pulled "... once the FSA considers the bank is 'failing or likely to fail to meet its threshold condition' and 'due to the circumstances the bank is not reasonably likely to turn its fortunes around so that it meets its threshold conditions'."32

The Act not only consolidates the tripartite arrangement as established under the 2006 Memorandum of Understanding, but is also evidential of the extension of the Bank of England's role in the supervisory process. ${ }^{33}$ This is reflected in sections such as those of 7 and 8 of the Act, which clarify responsibilities in relation to the exercise of powers. In respect of bank insolvency procedures, an insolvency order may be made only on the application of the FSA with the consent

27 „What the BSPA provided for was inter alia, a ready means for the Tripartite Authorities (Treasury, Bank of England and the Financial Services Authority, FSA) to transfer "the ownership or business of UK authorised deposit takers ... either into public ownership, or to another body in the private sector".

Temporarily taking a (deemed) failing British bank into public ownership involved a transfer of an institution's assets and liabilities and property rights, in whole or in part, for the time being to a 'bridge bank', being a wholly owned subsidiary which the Bank of England established for this purpose. This transfer was not envisaged as nationalisation per se, but rather an exercise in control even if, while in State hands (in the interim ownership of the bridge bank), the authorities might resolve to choose from two options ('resolution tools' as the options have been described) provided for from the point of view of the public interest in confidence in banking; its systemic stability; and minimising the cost to the taxpayer of crisis management.“ See F Raghallaigh and M Kennedy, „Banking Crises and Special Resolution Regimes“" February 2011 at page 39.

28 „Part 1 (stabilisation) provides for a capacity on the part of the authorities, acting according to law effectively to seize the balance sheets (with 'securities' and 'property' separately distinguished), in whole or in part, of a failing financial institution deemed essential to the systemic stability of the financial system. The language of the Act is not one of 'seizure', but rather 'transfer'. The outcome is (temporary) public ownership. The initiative lies with the state authorities (FSA trigger). There is no right of appeal (e.g. to the courts) that lies with the involuntary transferor." see ibid at page 42 .

29 See section 2 of the Act; See also section 1 (3a-c): These are a) transfer to a private sector purchaser b) transfer to a bridge bank, and c) transfer to temporary public ownership. Further, ,the Act provides that three stabilisation tools are available to the authorities in respect of the securities and property (business) transferred or taken over. They may be sold on to a third party (P\&A). They may be transferred to a bridge bank (see section 3.4 below) wholly owned by the Bank of England. Or, they may be put into temporary public ownership (TPO) in a Treasury owned, specially created banking entity. The toolkit is both calibrated and represents a ranking of preferences of the authorities, from a preferred sale post transfer to TPO (last resort). See F Raghallaigh and M Kennedy, „Banking Crises and Special Resolution Regimes“" February 2011 at pages 42 and 43.

30 As stated under Part 2.

31 As provided under Part 3.

32 See F Raghallaigh and M Kennedy, „Banking Crises and Special Resolution Regimes“ February 2011 at page 42 and also D Singh, The UK Banking Act 2009, Bank Resolution and Early Intervention: Policy and Practice, PowerPoint presentation, Symposium on Managing Systemic Risk, 7 - 9 April 2010, University of Warwick.

33 Financial Services Authority, ,, Memorandum of Understanding between HM Treasury, the Bank of England and the Financial Services Authority“" < http://www.fsa.gov.uk/pubs/mou/fsa_hmt_boe.pdf $>$ 
of the Bank of England, or on the application of the Bank of England. ${ }^{34}$ Further, before exercising insolvency powers in respect of a residual bank, the FSA is required to give notice to the Bank of England..$^{35}$

Germany is one of the most recent countries at this point in time, to legislate for a special framework within which to resolve banks that fall into difficulty - such a vehicle being provided by the Bank Restructuring Act or the Restrukturierungsgesetz (Restructuring Act). ${ }^{36}$

Three phases to the regime, as identified, are as follows: $:^{37}$

1. Restructuring (Sanierungsverfahren);

2. Reorganisation (Reorganisationsverfahren); and

3. Transfer (to bridge bank) (Übertragungsanordnung).

The rationale for such initiative having been outlined by the Finance Ministry: ${ }^{38}$

New rules are urgently required. The existing insolvency legislation and supervisory instruments are intended to freeze a company's operations. But doing so can negatively affect other financialmarket participants and the financial system as a whole. In the short term, state support measures, such as those brought in since the outbreak of the crisis in 2008, can limit the damage to financial markets.However, the government's ability to manage a crisis will remain limited as long as there is no mechanism for an orderly restructuring or resolution process. At the same time, if banks are certain the state will rush to the rescue in an emergency, this diminishes their sense of responsibility in the business decisions they take and creates an incentive to take on an uncontrollable level of risk. The government must not be left to pay for this with taxpayers' money."

Despite the above mentioned reforms, some gaps which persist across several jurisdictions, and indeed across the globe, have been highlighted by the Basel Committee in its recent report and are as follows: ${ }^{39}$

- The fact that many countries continue to lack important legal powers to resolve a financial institution in distress. ${ }^{40}$

34 See section 117(2) of the Act.

35 See section 157 of the Act.

36 „The legislation was first mooted on 31 March 2010, when the government advanced a set of proposals in a discussion paper (the 'key issues' paper). A bill was introduced to Parliament on 25 August 2010, passed with amendments in 28 October 2010 by the lower house and on 26 November by the upper house. The Act came into effect on 1 January 2011.“ See F Raghallaigh and M Kennedy, „Banking Crises and Special Resolution Regimes“ February 2011 at page 53.

37 „A comprehensive scheme which extends to prudential supervisory and regulatory reforms to provide for Prompt corrective Action (PCA) as well as for a crisis and resolution management regime (SRR) for SIFIs."; ibid.

38 See ibid

39 See Basel Committee on Banking Supervision, Resolution Policies and Frameworks - Progress So Far, July 2011, BIS Publications, particularly at pages 2 and $3<\mathrm{http}: / /$ www.bis.org/publ/bcbs200.pdf $>$

$40, \ldots$ And that where some powers are available, the lack of certain essential powers, including powers to terminate unnecessary contracts, continue needed contracts, sell assets and transfer liabilities, will risk making the resolution of the financial institution's affairs difficult and costly. The BCBS Recommendations identified these legal powers as typically useful to enhance the ability of resolution authorities to continue systemically important financial functions while conducting an orderly resolution or liquidation of the individual financial firm. While some progress has been made, much remains to be done. , see ibid at paragraph 6 page 2 . 
- Authorities in many countries appear to lack the legal powers to temporarily delay the operation of early termination provisions in financial contracts in order to complete a transfer of these contracts to a sound financial institution, a bridge financial institution or other public entity. ${ }^{41}$

- Shortcomings which continue to persist with respect to the resolution of a financial group, especially in a cross-border context.

- The fact that newly introduced tools or tools under consideration to deal with SIFIs, which include bridge bank powers or bail-in, are untested in many jurisdictions, or untested in their application to a complex multi-entity cross-border group or conglomerate.

- The uncertainty which remains in respect of the availability of temporary funding to support resolution measures.

- Significant differences which exist among the various deposit protection arrangements, which could complicate cross-border resolutions.

\section{Central Bank Independence}

Central bank independence is considered as a means of achieving the goal of price stability. ${ }^{42}$ It is also interesting to note that Lastra recommends the inclusion of regulatory powers in any law which truly safeguards independence. ${ }^{43}$ This would infer that central bank independence would be ensured if the central bank was responsible for both monetary policy setting and regulatory functions hence price stability would be better facilitated through a central bank whose powers not only consisted of monetary policy setting functions, but also of regulatory and supervisory functions. The strong record held by the Deutsche Bundesbank and in particular, the pre-1999 Bundesbank in maintaining price stability is reiterated. ${ }^{44}$ However, the difficulty in finding a central bank whose independence is absolute is also highlighted. ${ }^{45} \mathrm{In}$ as much as certain events and developments make it difficult to ensure that a central bank's independence is absolute, developments such as conglomeration and globalisation have warranted the need for the involvement of a single regulator. However, this is a function which if not absolutely carried out by the central bank, should still, to a great extent, involve the central bank.

There appears to be greater support for central bank independence when compared with independence granted to supervisory and regulatory agencies. Even though there is and there has been support for central bank independence - particularly with reference to independence from

41 „Even if these powers exist, it is not clear if they will be recognised where financial contracts are governed by foreign laws."

42 See RM Lastra, Legal Foundations of International Financial Stability 2006 45-46.

43 ibid at page 46.

44 ibid at pages 51-61.

45 „The Bundesbank's scope for independence has been restricted as a result of two major developments namely: The German unification and the European Monetary Union. In the case of German unification, the issue concerned national identity, not price stability. The Exchange Rate Mechanism of the European Monetary System was sacrificed in order to achieve the greater national objective of unifying the German people. With regards to the European Monetary Union, supranational integration was held to be more important for the future of the German nation than the maintenance of an independent central bank. "For further information on this, see ibid at 58-61. Lastra highlights the fact that the independence of the Bundesbank has seldom been sacrificed on the basis that the economy was suffering. 
political interference, there is still some reluctance to grant independence to financial regulators and supervisors. ${ }^{46}$ According to Hüpkes and others, it is more difficult for financial regulators to design accountability arrangements than it is for central banks. ${ }^{47}$ In their opinion, the reluctance by policy makers to grant independence to supervisory and regulatory agencies is attributed to three factors. ${ }^{48}$

The significance of central bank financial independence as a component of overall independence has been emphasised by the European Union. ${ }^{49}$ According to Buiter, ${ }^{50}$ two types of central bank independence exist, namely, target independence and operational independence. Four aspects of central bank independence are considered by Smaghi namely: ${ }^{51}$ functional, institutional, personal and financial independence. For the purposes of the discussion in this paper, operational and financial independence will constitute the focus of discussion.

\section{Central Bank Financial Independence}

Financial independence involves the independence of the central bank - when considered from the perspective of the funding of its activities and the exercise of its powers. ${ }^{52}$ In Amtenbrink's view, the central bank's legal basis may facilitate a system whereby a government which has been elected democratically determines the boundaries within which the central bank should decide on an actual capital increase. ${ }^{53}$ However, the success of such an arrangement would be dependent on the existence of a key factor, namely, the bank's independence from the government at the time when the actual need for re capitalisation occurs. ${ }^{54}$ Furthermore, central bank financial independence would be safeguarded where the central bank is not dependent on the government's general budget but is able to address the needs of its financial operations through its own generated income. ${ }^{55}$

According to Smaghi, ${ }^{56}$ legal provisions alone are generally not adequate to guarantee the appropriate level of central bank independence - the respect for independence and its boundaries, amongst parties involved, also being an important factor. He considers four elements of central bank independence, namely, functional, institutional, personal and financial independence. ${ }^{57}$ Furthermore, he goes on to state that:

"The concept of financial independence should therefore be assessed from the perspective of whether any third party is able to exercise either direct or indirect influence not only over the tasks

46 See EHG Hüpkes, M Quintyn, M Taylor, 'The Accountability of Financial Sector Supervisors: Theory and Practice 2006 at page 1 .

47 ibid, preface.

48 ibid at page 1; The three factors include: Firstly, the fact that independent regulatory and supervisory agencies could become another branch of government which is not subject to the same level of scrutiny as that which is prescribed to the executive, legislative and judicial branches. Secondly, without adequate regulatory oversight, regulators may favor industry interests over those of the public - hence facilitating the possibility of a "regulatory capture" occurring. Thirdly, self interest may contribute to policy makers' reluctance to giving up their oversight functions.

49 See P Stella and A Lönnberg, ,Issues in Central Bank Finance and Independence' IMF Working Paper WP/08/37 and in particular, the European Monetary Institute's report EMI (1998) "Convergence report” at page 295.

50 See W Buiter, 'What's Left of Central Bank Independence?' < http://blogs.ft.com/maverecon/2009/05/whats-left-ofcentral-bank-independence/>

51 See LB Smaghi, 'Central Bank Independence in the EU: From Theory to Practice' European Law Journal, Vol. 14, No. 4, July 2008.

52 See R Smits, ‘European Central bank Institutional Aspects’ 1997 Kluwer Law International at page 157.

53 F Amtenbrink, 'Securing Financial Independence in the Legal Basis of a Central Bank' at page 6.

54 ibid

55 ibid

56 See LB Smaghi, 'Central Bank Independence in the EU: From Theory to Practice' European Law Journal, Vol. 14, No. 4, July 2008, p. 446.

57 ibid 
of a central bank but also over its ability (understood both operationally, in terms of manpower, and financially, in terms of appropriate financial resources) to fulfil its mandate." 58

Ensuring absolute independence with central bank financial independence also constitutes a difficult task. This is illustrated by the close links which exist between the central bank and the Treasury in many countries. Is it possible for a central bank to operate effectively - given the presence of absolute independence? The importance of close collaboration and exchange of information between the tripartite authorities in the UK (the FSA, the Treasury and the Bank of England) was highlighted by the Northern Rock Crisis. These, if effective as they should have been, could have helped, not only in identifying the problems which existed at Northern Rock, ${ }^{59}$ but to facilitate timely intervention which would have averted the scale of the crisis.

\section{Operational independence}

This is defined as "...the freedom or ability of a central bank to pursue its objectives (regardless of who sets them) as it sees fit, without interference or pressure from third parties." ${ }^{\prime 60}$ In order for such independence to be effective, it is also argued that freedom from political influences is vital. ${ }^{61}$ As is the case with financial independence, absolute independence is extremely rare given the fact that the central bank, in many jurisdictions, is connected in one way or the other to the State and the sovereign. Illustrating with the scenario which exists in the UK, the central bank is owned by the Treasury $^{62}$ and several checks, for example, the role of the Treasury in underwriting risk attending emergency lending, are vital to ensuring accountability in matters relating to the central bank's position. ${ }^{63}$ Furthermore, regional and global developments are factors which may contribute to the status of independence attained by a central bank. For instance, the Bundesbank's scope for independence has been restricted as a result of two major developments namely: The German unification and the European Monetary Union. ${ }^{64}$

Arguments For and Against Central Bank Independence

\section{Arguments In Favour}

Need to ensure that central bank can act freely in pursuit of its objectives without interference from political pressures or other third parties.

Where operational independence exists, excessive interest rate cuts resulting from political

58 Ibid at 452 .

59 It should be added that a lot of factors contributed to Northern Rock's collapse - amongst which are the inadequacies of the measurements under Basel 2 and issues related to liquidity.

60 See W Buiter, 'What's Left of Central Bank Independence?' < http://blogs.ft.com/maverecon/2009/05/whats-left-ofcentral-bank-independence/>

61 ibid

62 W Buiter Central Banks and Financial Crises (Paper presented at the Federal Reserve Bank of Kansas City's symposium on "Maintaining Stability in a Changing Financial System" at page 40.

63 See P Stella and A Lönnberg, 'Issues in Central Bank Finance and Independence' IMF Working Paper WP/08/37.

64 See RM Lastra, Legal Foundations of International Financial Stability Oxford University Press 2006 at page 58. 
pressures could be avoided. ${ }^{65}$ However, excessive interest rates cuts may not be consequential of political pressures as they may arise through the application of the precautionary principle.

Other factors which may contribute to excessive interest rate cuts include extreme sensitivity to matters relating to the financial sector (which indicate "cognitive regulatory capture") and failures by strategic members of the FOMC to comprehend adequately the way in which the interest rate mechanism should operate (hence an inappropriate application of the mechanism). ${ }^{66}$ At times of high uncertainty, appropriate application of the interest rate mechanism as a tool of monetary policy should be timely, decisive and flexible and should focus on the principal risk. ${ }^{67}$

\section{Arguments against}

This could lead to abuse of powers. The level of independence granted should correspondingly be justified by sufficient checks and balances.

Regulatory capture: Bank collapses such as BCCI and Barings raised concerns regarding the ability of the Bank of England, as supervisor to separate itself adequately from the culture of the banking industry in order to enable it function as a truly independent supervisor and regulator. ${ }^{68}$ Due to lack of transparency, the kind of regime under which the Bank of England operated then, as regulator, a regime of informal and negotiated enforcement, was prone to two forms of abuse ${ }^{69}$ Firstly, it could degenerate into the capture of the regulatory system by the regulated, and secondly, it could conceal selective enforcement and possible harsh treatment of less significant regulatees. ${ }^{70}$

Close collaboration with other authorities may be vital to ensuring that complete, adequate and timely information relating to systemically relevant individual institutions is obtained.

Provided adequate balances and checks are in place to guard against any abuse that could result from a grant of independence, impediment to close collaboration between regulatory authorities should be overcome. Furthermore, adequate mechanisms of accountability should help to avoid a situation whereby regulatory capture could occur.

Having highlighted the fundamental role contributed by central banks to the regulatory and supervisory process and the importance of central bank independence, measures aimed at safeguarding an extension of such powers should be in place.

65 W Buiter, Central Banks and Financial Crises (Paper presented at the Federal Reserve Bank of Kansas City's symposium on "Maintaining Stability in a Changing Financial System" at page 113.

66 ibid at pages 113,114 .

67 See ibid pages 53 and 54; For further information on optimal decision making under uncertainty and whether regulator's focus should be directed at extreme risks, also see ibid at page 54 .

68 See Treasury and Civil Service Committee, Sixth Report: "The Regulation of Financial Services in the UK" House of Commons, (1994-1995) 332 para 108.

69 C Hadjiemanuil, Banking Regulation and the Bank of England 1995 Lloyds of London Press at page 182.

70 ibid 


\section{E. Measures Adopted in the Aftermath of the Recent Crises}

Following the introduction of the 2009 Banking Act in the UK, ${ }^{71}$ the following measures which are aimed at ensuring greater independent accountability, have been adopted correspondingly with an extension of the Bank of England's powers in regulation:

1) A new Financial Stability Committee (FSC), which is a product of the Act and which is a sub committee of the Court of Directors. ${ }^{72}$ It comprises of the Governor of the Bank, deputy governors and four non executive directors appointed by the chair of the Court. ${ }^{73}$ The functions of the Committee as stipulated in the Act are: ${ }^{74}$

To make recommendations to the Court of Directors, which they shall consider, about the nature and implementation of the Bank's strategy in relation to the Financial Stability Objective; to give advice about whether and how the Bank should act in respect of an institution, where the issue appears to the Committee to be relevant to the Financial Stability Objective; in particular, to give advice about whether and how the Bank should use stabilisation powers under Part 1 of the Banking Act 2009 in particular cases; to monitor the Bank's use of the stabilisation powers; to monitor the Bank's exercise of its functions under Part 5 of the Banking Act 2009 (inter-bank payment systems), and any other functions delegated to the Committee by the Court of Directors for the purpose of pursuing the Financial Stability Objective.

2) Efforts are being undertaken to facilitate the Bank's access to supervisory information with the Treasury indicating that the Bank will be able to make recommendations to the FSA in respect of its framework for regulation and supervision. ${ }^{75}$

3) The Turner Review which not only elaborates on ways in which responsibilities of a macro prudential nature could be allocated between the Bank and the FSA, but also on how this could be implemented. ${ }^{76}$

In Germany, the perception that the allocation of responsibilities between the Bundesbank and BaFin had lacked clarity and transparency resulted in the issue of a new Memorandum of Understanding in February 2008. ${ }^{77}$ This followed a series of government bailouts of state owned banks in 2008 - which in part, was attributed to the systemic importance assumed by such banks and the potential disastrous consequences which could occur if they had been allowed to fail. ${ }^{78}$ Close links exist between member banks of the German Savings Banks Finance Group (Sparkassen-

71 „The framework provided for by the Banking Act 2009 has been further developed in one important respect : living wills. The Financial Services Act 2010 (FSA/10) provides at section 7, for a duty on the FSA to require authorised firms to prepare and maintain 'living wills', or as they are formally referred to, recovery and resolution plans (RRPs). Section 7 in fact, is a detailed series of amendments to section 139 of the Financial Services and Markets Act 2000.“ See F Raghallaigh and M Kennedy, „Banking Crises and Special Resolution Regimes“ February 2011 at page 44.

72 See Bank of England, „News Release, Financial Stability Committee“ < http://www.bankofengland.co.uk/publications/news/2009/048.htm>

73 ibid

74 ibid

75 See W Nier, 'Financial Stability Frameworks and the Role of Central Banks: Lessons from the Crisis' IMF Working Paper WP/09/70 April 2009 page 21.

76 ibid

77 See W Nier, 'Financial Stability Frameworks and the Role of Central Banks: Lessons from the Crisis' IMF Working Paper WP/09/70 April 2009 at pages 21 and 22.

78 W Reuter, Spiegel Online ,"Worst Financial Crisis Since 1931?"

$<$ http://www.spiegel.de/international/business/0,1518,536635,00.html > 
Finanzgruppe) and as long as they are in the position to do so, they are required to bail each other out. The problem which existed at the time resulted from the fact that many of these banks were facing financial difficulties - hence were not in the position to assist other member banks. ${ }^{79}$

The crisis faced by IKB, Landesbanken and Hypo Real Estates not only revealed an absence of a special resolution regime for banks, but also raised the issue of optimal measures which could be implemented to control (in part) privately owned, but publicly-sponsored or (in part) publicly owned financial enterprises. ${ }^{80}$

\section{Conclusion}

Central banks have vital roles to play in the maintenance of price stability, achieving and maintaining stability within the financial system, and the provision of liquidity. A huge problem to be addressed at international level in efforts aimed at making cross-border resolutions more effective incorporates a lack of harmonization of insolvency laws. Other key issues which have been identified, as well as concrete steps that could be taken at international level to make crossborder resolutions more effective, include in particular, the following: ${ }^{81}$

- strengthening supervisory capacity of relevant national authorities and coordination through college structures in the pre-crisis phase;

- developing and maintaining knowledge and skills relevant to financial crisis resolution so that national authorities remain capable of responding quickly and effectively to financial crises; facilitating implementation of the new capital requirements to enhance loss absorbency, eg increased equity buffers and non-viability triggered convertible debt instrument; harmonising (or achieving greater convergence) at the international level of specific resolution powers, including property transfer and share transfer powers;

- ensuring through national law reform or mandatory change of financial contract terms that the exercise of certain resolution powers, such as property transfer powers, that promote continuity, do not trigger default thereby resulting in early termination of financial contracts; harmonising (or achieving greater convergence) of the scope of national resolution regimes (ie as regards the types of institution subject to such regimes) and extending the scope to non-bank financial institutions, including non-bank parent companies;

- enabling national authorities to implement group-wide resolutions in the case of distressed financial conglomerates; identifying and removing the specific legal obstacles to cross-border cooperation (eg confidentiality obligations preventing the cross-border sharing of information; preference of domestic creditors over foreign creditors; requirements under local law, such as local threshold conditions for authorisation, that prevent the operation of a bridge institution in a foreign jurisdiction;

79 ibid

80 W Nier, 'Financial Stability Frameworks and the Role of Central Banks: Lessons from the Crisis' IMF Working Paper WP/09/70 April 2009 at page 22.

81 Basel Committee on Banking Supervision, „Resolution Policies and Frameworks - Progress so Far“) at pages 40 and 41 
and establishing a framework for the cross-border recognition and enforcement of resolution measures and regulatory actions, which may take the form of high-level principles on cross-border coordination and cooperation."

\section{REFERENCES}

Amtenbrink F, 'Securing Financial Independence in the Legal Basis of a Central Bank' $<$ http://repub.eur.nl/res/pub/8350/>

Bank of England, „News Release, Financial Stability Committee“ $<$ http://www.bankofengland.co.uk/publications/news/2009/048.htm>

Basel Committee on Banking Supervision, Resolution Policies and Frameworks - Progress So Far, July 2011, BIS Publications

Buiter, W, Central Banks and Financial Crises (Paper presented at the Federal Reserve Bank of Kansas City's symposium on "Maintaining Stability in a Changing Financial System", at Jackson Hole, Wyoming, on August 21-23, 2008)

Buiter W, Central Banks and Financial Crises European Institute, London School of Economics and Political Science,

NBER and CEPR $<\underline{\text { http://www.nber.org/ wbuiter/hole.pdf }>}$

Buiter W, 'What's Left of Central Bank Independence?' < http://blogs.ft.com/maverecon/2009/05/whats-left-of-central-bank-independence/>

De Larosière, 2009, "Report of the High-level Group on Financial Supervision in the EU," Brussels, Feb 25, 2009

Deutsche Bundesbank, 'Deutsche Bundesbank's Involvement in Banking Supervision' Monthly Report (September 2000)

Deutsche Bundesbank, „Bundesbank and German Federal Financial Supervisory Authority (BaFin) $)^{\prime}<$ http://www.bundesbank.de/bankenaufsicht/bankenaufsicht bafin.en.php $>$

Federal Deposit Insurance Corporation, History of the Eighties: Lessons for the Future, FDIC, (1997) Washington DC, http://www.fdic.gov/bank/historical/history/

Federal Deposit Insurance Corporation, Managing the Crisis: The FDIC and the RTC Experience, FDIC,(1998) Washington DC http://www.fdic.gov/bank/historical/managing/contents.pdf

Financial Services Authority, , Memorandum of Understanding between HM Treasury, the Bank of England and the Financial Services Authority" http://www.fsa.gov.uk/pubs/mou/fsa_hmt_boe.pdf $>$

Goodhart C and Schoenmaker D ' Institutional Separation Between Supervisory and Monetary Agencies ' (Financial Markets Group Special Papers 1992 )140-141 
Goodhart CAE The Emerging Framework of Financial Regulation (1998)

Goodhart CAE, "Central Banks' Function to Maintain Financial Stability: An Uncompleted Task," VoxEU.org (June 24, 2008), http://www.voxeu.org/index.php?q=node/1263

Guha K, Fed Moves To Minimise Systemic Risk’ The Financial Times March 142008

Hadjiemanuil C, Banking Regulation and the Bank of England 1995 Lloyds of London Press

HM Treasury, Bank of England and FSA, 2008, "Financial Stability and Depositor Protection: Further Consultation,” July 2008

HM Treasury, „Banking Act 2009“ $<$ http://www.hm-treasury.gov.uk/fin_banking_act2009.htm>

Hüpkes EHG, Quintyn M, Taylor M, ‘The Accountability of Financial Sector Supervisors: Theory and Practice 2006

Lastra RM, Legal Foundations of International Financial Stability Oxford University Press 2006

Lawson J and Barnes S and Sollie M 'Financial Market Stability in the European Union: Enhancing Regulation and Supervision’ Economics Department Working Paper No. 670

Moffatt P and Campbell A, Emerging Changes to the United Kingdom's Financial-Sector Safety Net Following the Banking Crisis of 2007-2008 Banking \& Financial Services Policy Report Volume $30 \cdot$ Number 7 • July 2011

Muellbauer J, 'The Folly of the Central Banks of Europe' October 2008 $<$ http://www.voxeu.org/index.php?q=node/2488>

Nier W, 'Financial Stability Frameworks and the Role of Central Banks: Lessons from the Crisis' IMF Working Paper WP/09/70 April 2009

Raghallaigh F and Kennedy M, „Banking Crises and Special Resolution Regimes“ February 2011 Mazars Publications

Reinhart C and Felton A, 'The First Global Financial Crisis of the 21st Century: Part II, June December $2008<\underline{\text { http://mpra.ub.uni-muenchen.de/13604 }>}$

Reuter W, Spiegel Online ,"Worst Financial Crisis Since 1931?"“

$<$ http://www.spiegel.de/international/business/0,1518,536635,00.html $>$

Schoenmaker D and Oosterloo S, "Financial Supervision in Europe: A Proposal for a New Architecture", in: L. Jonung, C. Walkner and M. Watson (eds), Building the Financial Foundations of the Euro - Experiences and Challenges, 2008 Routledge, London.

Singh D, The UK Banking Act 2009, Bank Resolution and Early Intervention: Policy and Practice, PowerPoint presentation, Symposium on Managing Systemic Risk, 7 - 9 April 2010, University of Warwick.

Smaghi LB, 'Central Bank Independence in the EU: From Theory to Practice' European Law Journal, Vol. 14, No. 4, July 2008

Smits R, 'European Central bank Institutional Aspects’ 1997 Kluwer Law International

Stella P and Lönnberg A, ,Issues in Central Bank Finance and Independence' IMF Working Paper 
WP/08/37 and in particular, the European Monetary Institute's report EMI (1998) "Convergence Report"

Treasury and Civil Service Committee, Sixth Report: "The Regulation of Financial Services in the UK” House of Commons, (1994-1995) 332 para 108 